\title{
DIGITALCOMMONS
}

@WAYNESTATE-

Criticism

Volume 62 | Issue 1

Article 8

2020

\section{Asian American Sociality after the Anti-Relational Turn in Queer Theory}

Kai Hang Cheang

Portland State University, kai.cheang@email.ucr.edu

Follow this and additional works at: https://digitalcommons.wayne.edu/criticism

\section{Recommended Citation}

Cheang, Kai Hang (2020) "Asian American Sociality after the Anti-Relational Turn in Queer Theory," Criticism: Vol. 62 : Iss. 1 , Article 8.

Available at: https://digitalcommons.wayne.edu/criticism/vol62/iss1/8 
ASIAN AMERICAN

SOCIALITY

AFTER THE ANTI-

RELATIONAL TURN

IN QUEER THEORY

Kai Hang Cheang

Inscrutable Belongings: Queer

Asian North American Fiction

by Stephen Hong Sohn. Palo Alto:

Stanford University Press, 2018.

336 pp. $\$ 90.00$ cloth, $\$ 30.00$ paper.

Sticky Rice: A Politics of

Intraracial Desire by Cynthia

Wu. Philadelphia, PA: Temple

University Press, 2018. 212 pp.

$\$ 94.50$ cloth, $\$ 29.95$ paper.
In the midst of the HIV epidemic and the conservative politicization of homosexual desire, a cohort of queer theorists, including Leo Bersani and Lee Edelman, began to question whether heteronormative society will ever accommodate nonhomonormative gays and lesbians, and whether queer people should therefore engage with heteronormative notions of progress and futurity. Their arguments, often labeled as anti-relational or anti-social, continue to influence how queer scholars understand the social and what sociality can do for the improvement of queer lives. The recent relational turn in Queer Asian American Studies takes into consideration these questions as it builds on queer theory's critique of heterosexual couplings while turning to Asian American literature to illuminate the personal and political efficacy of queer love and kinship. Both published in 2018, Stephen Hong Sohn's Inscrutable Belongings: Queer Asian North American Fiction and Cynthia Wu's Sticky Rice: A Politics of Interracial Desire theorize queerness as an individual and collective orientation that resists heterosexual mandates and the scrutinizing gaze of the white nation-state. By focusing on the coalitional dimensions of sociality, Sohn's and Wu's books are Asian American Studies' contributions to the (anti)relational debate: their work foregrounds 
the differences collectivity makes to queer Asian lives in North America. To fully detail Wu's and Sohn's contributions to the debate, it is necessary to offer a brief overview of the (anti)relational thesis.

Inspired by the Freudian pleasure principle and the death drive, Bersani and Edelman, respectively, offer distinctive versions of the anti-social thesis. In "Is the Rectum a Grave" (1989) Bersani argues that there is redemptive value in non-political practices like BDSM because they can usher practitioners into uncomfortable yet pleasurable dispositions that are symbolic of the new vantage point made accessible by relinquishing one's control over the body to the hands of the other. In No Future (2004), Edelman advocates for an even more antiassimilationist vision of queer life, one predicated on the notion of queer refusal. Retreating from politics, for Edelman, is the ultimate queer refusal, since he does not see a space in heterosexual society where queer people can find refuge from the continuous persecution imposed by reproductive culture.

Influential as it has been, the anti-relational thesis assumes a high degree of individual autonomy and has therefore become a target of criticism by queer theorists of color and other critics who embody multiple identarian differences. Jack Halberstam, for instance, homes in on the privilege that the anti-social argument exudes, noting that "the gay male archive [may have] coincided with the canonical archive, and [thus] narrow[ed] it down to a group of antisocial queer aesthetes." José Esteban Muñoz also critiques the anti-relational camp's privilege, arguing that children of color do not share the cultural advantages that mark the figural Child that Edelman so resolutely rejects. Muñoz goes on to argue that queer youths cannot afford to give up on the imagination of a utopic future as political optimism is what keeps them alive. Given the life-giving potential of utopic futurity, Muñoz finds the anti-relational turn alienating to people of color and goes on to call it "the gay white men's last stand" in queer studies. ${ }^{2}$

Sohn's Inscrutable Belongings and Wu's Sticky Rice build on Halberstam and Muñoz's anti-anti-relational thesis. Through different paths, the Asian American queer theorists argue that same-sex desires and nontraditional forms of families are politically subversive and potentially nourishing. These monographs offer a third way out from the polemics of Bersani and Edelman - which set out to abandon the political in the name of self-preservation-and those of Halberstam and Muñoz-which seek to carve out queer utopias (that perhaps are only possible 
in negative spaces such as the non-place). Strategically pragmatic, Wu's and Sohn's monographs de-sublimate queerness from an abstract ideal to a concrete praxis of social formation, while also managing to maintain the elusiveness that is necessary for the defense of any radical queer sociality. The formation of "sticky rice" enables $\mathrm{Wu}$ to mull over the possibilities of samesex relations without fixating on one as the archetype for a queer Asian American collectivity, while "inscrutable belongings" as a metaphorical notion permits Sohn to trace out a range of nonarboreal kinships that span across the boundaries of nations and times. The elasticity of these relational figurations allows $\mathrm{Wu}$ and Sohn to avoid the criticism of "chiasmic inversion" (822), in other words, the substitution of the subject of critique with an oppositional replacement, that Edelman levels against Halberstam for "idolizing" "punk pugilism" (822) as the anti-authoritarian essence of queer negativity, which, per Edelman, should be devoid of content and therefore indefinitely deconstructive in nature. For instance, "sticky rice" is commonly referred to as a type of opaque grain; and "inscrutability," according to the $O E D$, is a nonphysical property used to describe something unfathomable like an "abyss." Wu and Sohn find potential in the capaciousness of these notions and use them to sketch out the larger contours of multiple queer Asian groupings without having to essentialize any one of them.

It is perhaps no surprise that metaphor is a kin-making device for queer novelists: in the absence of something quantifiable like biological relations, the ability of a queer individual to see parallels between different lives becomes essential in their formation of family-by-choice. Sohn's project neatly articulates this. He charts out the networks that pathology (like trauma) and psychic power (like aspiration) form in the genre that he characterizes as the "survival plot." Taking a structuralist approach, each chapter (other than the first one) in Inscrutable Belongings chronicles the ways queer characters in survival plots draw collective strength from each other to endure literal and social deaths. Chapter 2, for instance, traces how the mourning of the death of an HIV/AIDS victim brings together a fraternal belonging of gay Asian men across ethnic lines in Russell Leong's short story "Camouflage." Chapter 3 examines Alexander Chee's Edinburgh with a specific attention paid to the protagonist's, Fee's, spiritual mentorship by the fox demon of Korean legends as he seeks to recover from the trauma of childhood molestation. Sohn emphasizes the continuity of Fee's 
queer kinship as he points out how Fee not only survives pathology by the end of the novel but further extends his queer lineage by donating his sperm to his friend, Penny, for artificial insemination. Chapter 4 continues on with the exploration of figurative kinship between queer characters who live in different times and spaces. The inscrutable belonging in this chapter manifests in the transhistorical desire that the aspiring Asian character Bong Bong Luwad holds for Montgomery Clift, one of the alleged pioneering queer actors in Hollywood. Though admiration for Clift keeps Luwad alive and active in the movie industry, the racial difference between the two causes Luwad to realize a specific set of discriminations that faces Asian American male actors.

Chapters 5 and 6 turn from novels that center on gay men to those that center on lesbians; these texts include Nina Revoyr's Wingshooter and Lydia Kwa's Pulse. With the hermeneutic of inscrutable belongings that he established in the first four chapters, Sohn in these last chapters is able to use the concept to position communities that are often caricatured as rooted in aggression-such as the hunting community (in Wingshooter) and the bondage subculture (in Pulse)_as support groups that provide lesbian characters reprieves from oppression and alienation. As a whole,
Sohn's book is a valuable addition to Queer Asian American Studies because it not only advances an optimistic vision of queer lives but also pieces together a unique textual archive composed of novels by queer-identifying authors that we don't see very often in the field.

Wu's Sticky Rice was published two months after Inscrutable Belongings. Like its figurative sibling, the book utilizes metaphor in its process of argumentation. "Sticky rice" is the metaphor for Asian gay men who are attracted to other gay Asian men. The term "sticky rice" first originated in China and refers to the type of Chinese dumplings that people eat every year during the Dragon Boat Festival. The culinary tradition began in China after the poet $\mathrm{Qu}$ Yuan drowned himself in the Milou River in 278 A.D. following his failed attempt to warn his people of an invasion from the state of Qin. Qu's compatriots loved the poet so much so that they began to make sticky rice dumplings and throw them into the river every year on June 7-the day Qu died-in the hopes of distracting the fish in the river from nibbling at Qu's corpse. As the term has evolved from being a token that commemorates a nationally loved hero to a metaphorical shorthand for same-sex coupling, the revolutionary history behind the food item has been mostly lost in the queer American vernacular. 
But what "sticks" in sticky rice after its two reincarnations is the homogeneity of the objects that stick together-first, the rice in the rice-based carp bait and second, queer Asians. Wu's theorization of the term mines that intragroup homogeneity by labeling stickiness an "intra-racial resolution" (16) to the infamous Chin-and-Kingston debate in Asian American studies, a proposition that puts into productive conversation the nationalistic and queer subtexts of sticky rice's two meanings.

For Wu, "sticky rice" is a mode of "self-actualized coalition building" (19) that has a distinctively homoerotic underpinning. $\mathrm{Wu}$ flirts with the boundary between gay and straight by arguing that homosexuality and homosociality are two sides of the same spectrum. With that objective, $\mathrm{Wu}$ takes on the task of queering an Asian American literary canon with texts that are often thought of as masculinist and culturally nationalist.

In chapter $1, \mathrm{Wu}$ zeros in on the covert homoerotic desire shared between Kenji (a Japanese American WWII veteran) and his friend Ichiro (a draft resister) in John Okada's No-No Boy. Wu's close reading treats Kenji's prosthesis as a metaphoric stand-in for the phallus that vicariously consummates the love between Kenji and Ichiro. Chapter 2 speculates on the scenario of an intra-ethnic reunion between South Vietnamese refugees and Vietnamese communists in the context of Monique Truong's novel Bitter in the Mouth. There, $\mathrm{Wu}$ concentrates on the pick-up scene-on the bridge-between Gertrude Stein's Vietnamese cook, Binh, and the anonymous character who turns out to be Ho Chi Minh. Afterwards, according to Wu's analysis of Truong, the two Vietnamese have sex, which is suggested by the novelist's strategic employment of terse language and signifying erasures.

Chapter 3 analyzes the mentorship between two Asian American actors, Vincent and Bradley, in Philip Kan Gotanda's Yankee Dawg You Die. Wu deploys the two men's "perverse queerness" (104) as a touchstone to criticize a liberal multiculturalism that promises false racial and sexual inclusivity. As the character Vincent said, it is true that being gay "does not matter" (qtd. in Wu 89) to an actor's career as it once did; however, as $\mathrm{Wu}$ reminds us by drawing on interviews conducted with real life Asian performers and observations of their careers, liberal multiculturalism's acknowledgment of minority identity can be just as suffocating as the closet, because token inclusion can limit the roles that a queer and ethnic actor can play.

Chapter 4 centers on Hsi Tseng Tsing's And China Has Hands. 
Just as she does in chapter $1, \mathrm{Wu}$ looks for the language of the phallus, and in this case, it is the anonymous character's sock-clad-fist. Interpreted through the lens of homoerotic innuendoes, $\mathrm{Wu}$ argues that the sight of metaphoric fisting gives joy to and connects the anonymous character, a writer who is granted an exception to enter the US despite the Asiatic Barred Zone Act, with Wong Wan-Lee, a laundryman - constituting a crossclass union that is synecdochic of a laborer's resistance at the backdrop of the novel. Wu's last chapter, like that of Sohn's, shifts its focus from male-male coupling to that of two women. Centering on the child-rearing co-domestication of the two Japanese American characters Big Sis and Sandi at the end of Lois-Ann Yamanaka's Blu's Hanging, Wu conjectures about the outlook of a queer future in Hawai'i. She worries that it "would be more of the same" (159) if the queer east Asians in Hawai' $i$ were to remain oblivious to their (ancestors') complicity in settler colonialism.

Taken as a whole, Wu's monograph is in keeping with and adds important insights to the recent surge of titles that review the history, missed opportunities, and blind spots of the past formations of Asian America as an intra-ethnic coalition. ${ }^{3}$ Wu's contribution is her queer approach to the analysis of social formation: her formulation of "sticky rice" makes namable the silences and clandestine objects that triangulate Asian Americans' desire for and identification with each other in race-based movements.

When read side by side, Sohn's and Wu's monographs pose questions to one another: the exclusively queer textual corpus in Inscrutable Belongings asks Sticky Rice why it does not include texts that are written by queer-identifying writers; conversely, Sticky Rice's political commitment in civil rights movements challenges Inscrutable Belongings to come up with a means of coping with oppression that goes beyond a kinship of mere survival. Nonetheless, the fact that these two works on queer Asian American sociality bring together such different cultural texts and generate distinctive conversations proves their value to Queer Asian American Studies. As a pair, they offer fresh perspectives on foundational discussions about gender, sexuality, cultural nationalism, and literary formalism, providing scholars and students of not only Asian American Literary and Cultural Studies but also the larger field of Critical Race, Gender, and Sexuality Studies new departure points from which to re-calibrate the political and social meanings of representations of queer belongings. 
Kai Hang Cheang is visiting assistant professor in the Department of Women, Gender, and Sexuality Studies at Portland State University. His first book project traces the modalities and trajectories of queer temporalities in the poetry, performance, and photography of postcolonial and diasporic Hong Kong. His essays have appeared in MELUS, Pacific Coast Philology, Alif, Gender Forum, and Social Text Online.

\section{NOTES}

1. Robert L. Caserio, Lee Edelman, Judith Halberstam, José Esteban Muñoz and Tim Dean, "The Antisocial Thesis in Queer Theory," PMLA 121, no.3 (2006): 824, https://www.jstor.org/ stable/25486357? seq $=1$

2. Caserio et al, 825 .

3. See Daryl Joji Maeda's Rethinking the Asian American Movement (2011s and Karen L. Ishizaka's Serve the People: Making Asian America in the Long Sixties (2016). 
